\title{
Changes in plasma cortisol, plasma $\beta$-endorphin, heart rate, haematocrit and plasma protein concentration in horses during restraint and use of a naso-gastric tube
}

\author{
Eva Hydbring ${ }^{1}$, Sara Nyman² and Kristina Dahlborn ${ }^{1}$ \\ 'Department of Animal Physiology, ${ }^{2}$ Department of Medicine and Surgery, Swedish University of Agricultural Sciences, Uppsala, Sweden
}

\begin{abstract}
Summary
Tubing and restraint are used in order to administer fluid, antihelminthic drugs or to perform gastroscopic examinations. The aim of this study was to investigate if the stress response of horses differ between the following treatments; Upper lip twitching, Holding the ears of the horse and naso-gastric tubing, Upper lip twitching and naso-gastric tubing, and Upper lip twitching and naso-gastric tubing with administration of 10 litres body warm saline solution, $9 \mathrm{~g} \mathrm{NaCl} / \mathrm{l}$. Five Standardbred geldings underwent the treatments at random. Entering the treatment room increased the haematocrit and plasma protein concentration. The heart rate decreased in treatments where the twitch was used. All treatments elevated the plasma cortisol concentrations. The horses behaved most disturbed when they were tubed without twitching, but the plasma $\beta$-endorphin concentration increased only when twitching was combined with naso-gastric tubing.
\end{abstract}

Keywords:

horse, naso-gastric tube, restraint, stress, twitch

Veränderungen der Konzentration von Kortisol, $\beta$-Endorphin und Gesamtprotein im Plasma sowie des Hämatokrits und der Herzfrequenz bei Pferden unter Zwangsmaßnahmen in Kombination mit einer Nasenschlundsonde

Das Anlegen einer Nasenbremse und einer Schlundsonde stellen beim Pferd gängige Maßnahmen dar, um Flüssigkeiten oder Anthelmintika zu verabreichen oder eine Magenendoskopie durchzuführen. In dieser Studie werden die Auswirkungen verschiedener Zwangsmaßnahmen auf bestimmte Parameter beim Pferd getestet, welche im Zusammenhang mit Streßreaktionen stehen.

Um eine Nasenschlundsonde zu schieben, werden unterschiedliche Zwangsmaßnahmen beim Pferd verwendet. In diesem Experiment kamen die Nasenbremse und das Abknicken eines Ohres zur Untersuchung, wobei die Zwangsmaßnahmen allein und in Kombination mit der Nasenschlundsonde getestet wurden. In einem Teil des Versuchs wurde den Pferden noch 10 Liter körperwarme Kochsalzlösung über die Sonde eingegeben.

Die Reihenfolge der vier Behandlungsarten erfolgte nach dem Zufallsprinzip. Als Streß-Indikatoren dienten die Kortisol- und $\beta$-Endorphingehalte im Plasma sowie Hämatokrit und Herzfrequenz der Tiere. Um Veränderungen im Plasmavolumen zu erkennen wurde der Gesamtproteingehalt im Blutplasma bestimmt. Den Wallachen wurde einige Stunden vor Beginn des Versuch ein Dauervenenkatheter gelegt und die Basiswerte der verwendeten Streßparameter bestimmt.

Die Pferde wurden bei allen Experimenten von denselben Personen betreut. In bestimmten Intervallen wurde den Tieren während und nach den einzelnen Versuchen Blut entnommen. Bereits beim Betreten des Behandlungsraumes stiegen der Hämatokritwert und der Plasmaproteingehalt der Tiere deutlich an. Die Pferde reagierten sehr unterschiedlich auf das Einsperren im Zwangsstand und die einzelnen Maßnahmen. Eines wurde eher ruhig, eines fast apathisch, ein anderer Wallach wurde sehr lebhaft. Die Herzfrequenz verringerte sich bei allen Pferden nach Anlegen der Oberlippenbremse. Bei sämtlichen Behandlungen wurde ein Anstieg des Plasmakortisolspiegels beobachtet.

Die Pferde verhielten sich besonders unruhig, wenn die Schlundsonde ohne vorherige Zwangsmaßnahmen geschoben wurde. Ein Wallach zeigte sich während aller Behandlungen nervöser als die anderen Tiere. Bei ihm gelang es auch nicht, die Nasenschlundsonde ohne Oberlippenbremse zu schieben.

Beim Versuch, die Sonde ohne Zwangsmaßnahmen zu installieren, wurden keine erhöhten $\beta$-Endorphinkonzentrationen gemessen. Der $\beta$-Endorphingehalt im Plasma stieg nur bei den Experimenten an, bei denen die Nasenbremse in Kombination mit der Schlundsonde eingesetzt wurde.

Schlüsselwörter: Pferd, Nasenschlundsonde, Zwangsmaßnahmen, Streß, Nasenbremse

\section{Introduction}

Stress is a normal part of life and lack of stress may lead to boredom rather than comfort. However, it is important to distinguish between physiological stress, the normal harmless adaptive response, and the potentially damaging responses of distress. Because we are unable to determine the presence of mental suffering in animals, assessment of well-being is based on physiological, immunological, behavioural and anatomic indicators of stress and distress (Benson, 1995). Different physio- logical variables, mainly hormones, have been used in order to objectively evaluate the effects of a stressful situation. The body responds to increased physical and psychological demands by release of cortisol from the adrenal cortex and $\beta$-endorphin from the pituitary. The sympathetic nervous system (fight- or flight response) is activated which leads to increased release of adrenaline and noradrenaline into the blood. The heart rate accelerates and the blood pressure rises. Activation of the sym- 
pathetic nervous system in horses, stimulates the spleen to contract and release stored red blood cells into the circulation. Consequently, an increased haematocrit value is an indirect marker of a stimulated sympathetic nervous system. Apart from splenic contraction, the haematocrit is also affected by plasma volume changes. Activation of the sympathetic nervous system may cause protein free fluid to leave the vascular compartments causing the haematocrit and the plasma protein concentration to rise. Transport of fluid or water into the vascular compartments decreases both the haematocrit and the plasma protein concentration.

Handling large domestic animals like horses requires knowledge and the method of restraint depends on many factors, e. g. the individual, procedure to be performed, equipment, available help and drugs. The general methods of physical restraint in horses include halter and lead, skin twitch, ear hold and nose or lip twitch Naughan and Allen, 1982). The lip twitch usually makes the horse quiet and calm. Information concerning the mechanisms behind the sedating effect of the twitch is scarce and several explanations have been proposed to elucidate its mode of action. One suggestion is that the twitch activates pain receptors which blocks the nerve impulses from other painful stimuli (Lagerweij, Nelis and van Ree, 1982). However, Lagerweij and Nelis (1984) studied twitching in the horse and found that this can not serve as a plausible explanation since there were no signs that twitching caused pain. Instead, the horses appeared to be sedated and the heart rate was reduced, while painful stimuli activated the horses and increased heart rate. The authors suggested that twitching is more comparable to neuroleptic analgesia and acupuncture.

Tubing horses is used in order to administer fluid, antihelminthic drugs or to perform gastroscopic investigations. Restraint and passing a tube into the stomach may be stressful for the horse and may influence the therapy and fluid uptake. Therefore, the aim of the study was to register the behaviour of the horses in relation to changes in physiological stress variables during different combinations of restraint and tubing. Are some moments more stressful than others? In this study we chose to analyse plasma cortisol, plasma $\beta$-endorphin, heart rate and haematocrit as indicators of stress. In addition, we measured the total plasma protein concentration as a marker of plasma volume changes.

\section{Materials and methods}

\section{Animals and experimental procedure}

The Uppsala Local Ethics Committee approved both the care of the horses and the study. Five Standardbred geldings, aged 4-9 years, were used. The horses underwent four treatments at random order during four days. The treatments were: Upper lip twitching (TW), Holding the ears of the horse and naso-gastric tubing $(\mathrm{HN})$, Upper lip twitching and naso-gastric tubing (TWN), and Upper lip twitching and naso-gastric tubing with administration of 10 litres body warm $\left(38^{\circ} \mathrm{C}\right)$ saline solution, $9 \mathrm{~g} \mathrm{NaCl} / \mathrm{I}$ (TWNS). The same persons handled the horses in all treatments; one applied a rope twitch around the upper lip, one inserted the naso-gastric tube into the stomach, one recorded heart rate and took blood samples and one firmly grasped one hand around each ear of the horse or poured the saline solution into the tube. All horses were well accustomed to handling and experiments before the study, but one of the horses was more nervous than the other four. We did not manage to apply the naso-gastric tube into that horse without using the twitch so he did not participate in treatment HN. In the morning, on the experimental day, a catheter was inserted into one of the jugular veins under local anaesthesia (Xylocain ${ }^{\circledR}$, Astra, Södertälje, Sweden) and provided with an extension tube. Thereby, blood could be withdrawn without disturbing the horse. The first blood sample was taken in the box at $08.00 \mathrm{~h}$, immediately before feeding. After two hours, when the horses had finished their morning feed, the first horse was taken to a stock in a room next to their stable. A second blood sample was withdrawn and the horse received one of the four treatments. All treatments lasted for $10 \mathrm{~min}$, i. e. the application of the twitch and/or the tube went on during this time. Blood samples were taken 2, 4, $6,10,15,20$ and 30 min after the treatment had started. After 30 min the horse was brought back to its box, where blood samples were withdrawn 60, 90 and 120 min after onset of the treatment. The horses were taken out in the same order all experimental days with the first horse receiving the treatment at $10.00 \mathrm{~h}$ and the fifth at $14.00 \mathrm{~h}$. Before blood sampling, the heart rate was monitored with a phonendoscope. The control heart rate in the box is a mean value from an earlier experiment with the same animals. The behaviour of the horse was registered continously.

\section{Analyses}

Blood was collected into ice-chilled tubes containing $K_{3}$-EDTA and aprotinin (Trasylol $^{\circledR}$, Bayer, Leverkusen, Germany) for cortisol and $\beta$-endorphin analyses. The plasma concentrations of cortisol and $\beta$-endorphin were determined by radioimmunoassays (RIA). Cortisol was detected by the kit "Coat-A-Count" (Diagnostic Products Corporation, Los Angeles, USA) which was evaluated for horse plasma by the corporation and Klein et al. (1989). The concentration of $\beta$-endorphin was analysed by kits from INCSTAR corporation (Stillwater, Minnesota, USA). This assay has been evaluated for horse plasma by Hamra et al. (1993). For measurement of haematocrit and plasma protein concentration blood was collected in tubes containing Li-Heparin. For haematocrit determinations, blood was centrifuged in duplicates in capillary tubes for 5 min (ALC ${ }^{\circledR}$ Centrifugette 4203, Skafte \& Claesson AB, Göteborg, Sweden). Total plasma protein concentration was estimated by refractometry (Reichert-Jung, Cambridge Instruments Inc. Buffalo, NY 1415, USA).

\section{Statistics}

Data were examined by analysis of variance using the General Linear Model procedure of Statistical Analysis System (SAS Institute Inc., 1987). For testing significances within treatment paired t-test was used. The second sample was used as the reference value. For testing differences between treatments the variation between horses within treatment was used as an error term. When testing differences between treatments, the treatment was divided in four blocks; first sample, second sample, sample 3-9 (= stock period) and sample 10-12. There were no significant differences between treatments in the first and second control values. Significance was set at $P \leq 0.05 . N=5$ in all treatments except in treatment $\mathrm{HN}(\mathrm{N}=4)$. Values are presented as means \pm standard errors (SE). 


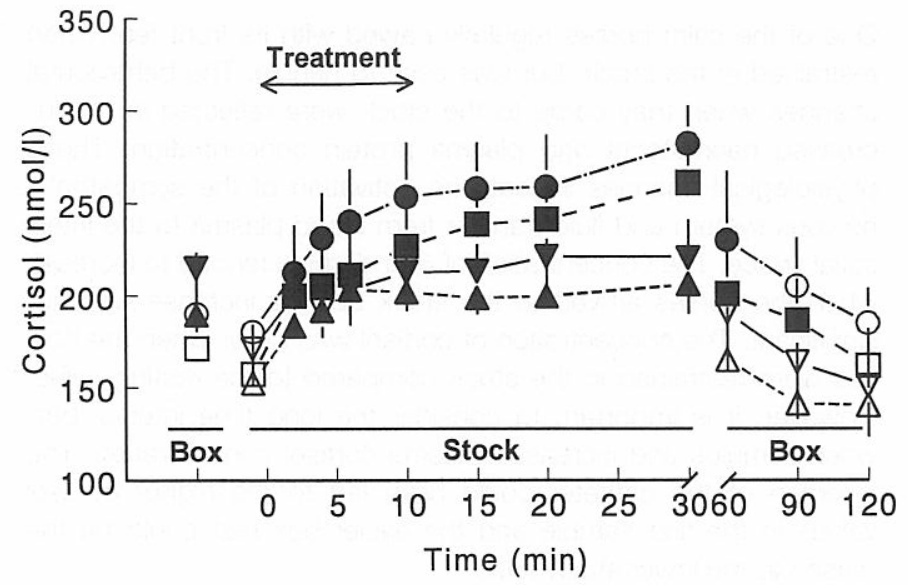

Fig. 1: The plasma concentration of cortisol during four treatments in horses. The treatments were enforced for $10 \mathrm{~min}$ each time. $\nabla-\nabla=$ Upper lip twitching (TW), $\Delta---\Delta=$ Earholding and naso-gastric tubing $(\mathrm{HN}), \mathrm{O}-\cdot-\mathrm{O}=$ Upper lip twitching and naso-gastric tubing (TWN), $\square--\square=$ Upper lip twitching and naso-gastric tubing with administration of $10 \mathrm{I}$, body warm $\left(38^{\circ} \mathrm{C}\right)$ saline solution, $9 \mathrm{~g} \mathrm{NaCl} / \mathrm{l}$ (TWNS). $\mathrm{N}=5$ in all treatments except in $\mathrm{HN}(\mathrm{N}=4)$. Means \pm SE. Symbols are filled when the values are significantly different from the second sample, $\mathrm{P}<0.05$. There were no significant differences between treatments.

\section{Results}

\section{Behaviour}

The horses were familiar with the stock from earlier experiments and probably anticipated that something would happen because they became alerted when they entered the treatment room. When they were restrained in the stock the individuals showed different behaviour. One became very alert, tried to throw its head back and get away from the stock, two became calm and quiet, one was quiet but pawed regularly with both front feet, and the last horse seemed apathetic but tense. The behaviour during application of the twitch also varied between the horses. The

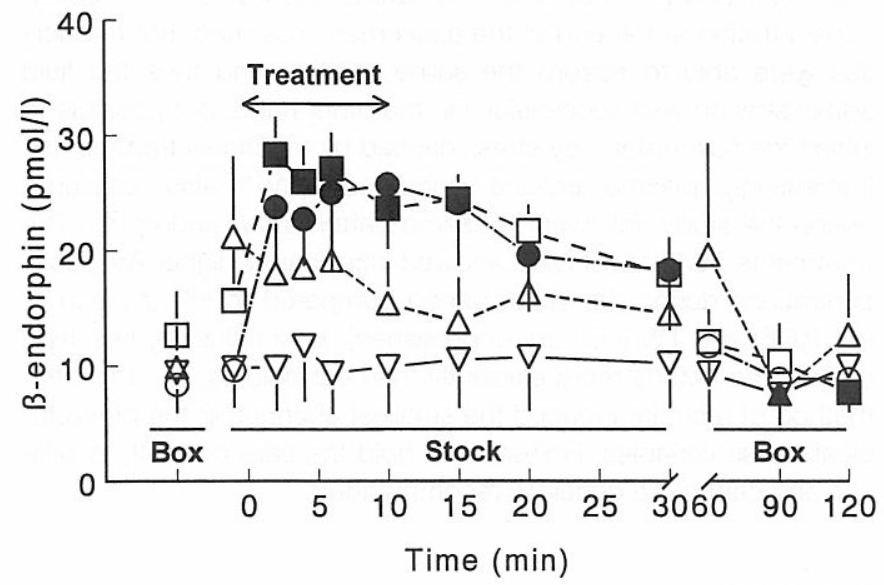

Fig. 2: The plasma concentration of $\beta$-endorphin during the same four treatments as described in Fig 1. Means \pm SE. The following treatments differed significantly during the stock period: TW $\longleftrightarrow$ TWNS $(\mathrm{P}<0.05)$.

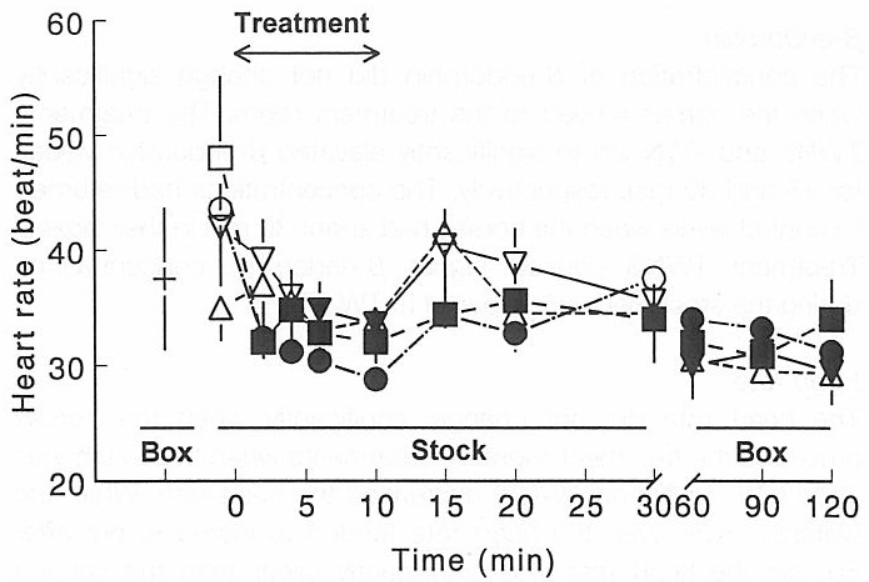

Fig. 3: Heart rate during the same four treatments as described in Fig 1. + =Mean resting value from earlier experiment with the same horses. Means $\pm \mathrm{SE}$. The following treatments differed significantly during the stock period: TW TWN $(\mathrm{P}<0.01)$.

alerted horse became calm, almost sedated, and easy to handle. One of the quiet horses, the pawing horse and the tense horse also became calmer, but the second quiet horse instead became irritated during twitching. Four of the horses appeared most upset when they were ear held and tubed (treatment HN). The already alerted horse became so excited that we failed to insert the tube. However, one of the quiet horses became most calm when he was ear held and was easily tubed.

\section{Cortisol}

Compared to the first box value, the plasma cortisol concentration in TW and HN was lower when the horses had entered the stock. The concentration increased immediately during all treatments and remained elevated as long as the horses stayed in the stock in treatment TW and HN. In TWN and TWNS the cortisol concentration remained elevated for 60 and $90 \mathrm{~min}$, respectively. There were no significant differences between treatments either in the stock or afterwards (Fig. 1).

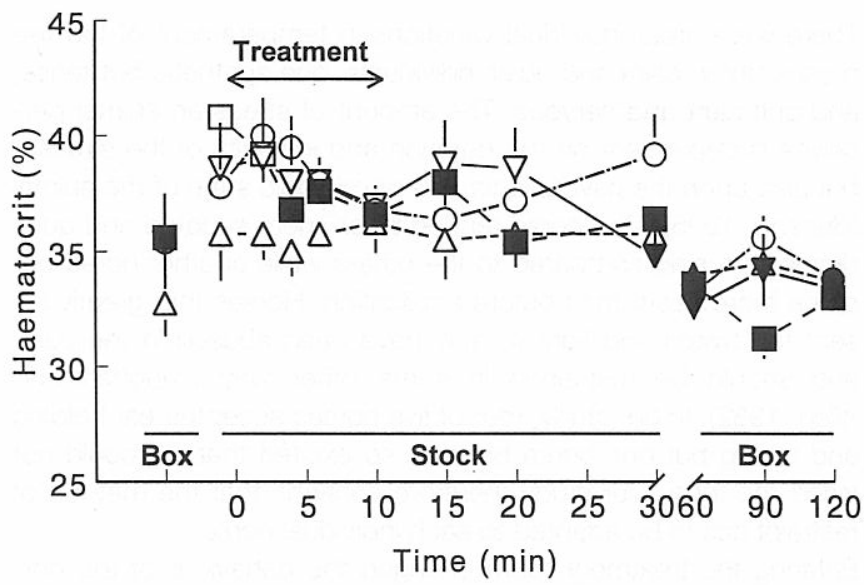

Fig. 4: The haematocrit during the same four treatments as described in Fig 1. Means \pm SE. There were no significant differences between treatments. 


\section{$\beta$-endorphin}

The concentration of $\beta$-endorphin did not change significantly when the horses arrived to the treatment room. The treatments TWNS and TWN led to significantly elevated $\beta$-endorphin values for 15 and $30 \mathrm{~min}$, respectively. The concentrations had returned to control levels when the horses had spent $30 \mathrm{~min}$ in their boxes. Treatment TWNS caused higher $\beta$-endorphin concentrations during the stock period compared to TW (Fig. 2).

\section{Heart rate}

The heart rate did not change significantly when the horses arrived to the treatment room. All treatments when the twitch was used (TW, TWN and TWNS) decreased the heart rate. When the twitching was over, the heart rate tended to increase, but after 60 min the heart rate was significantly lower than the second sample in all treatments except HN. Treatment TWN led to significantly lower heart rate during the stock period compared to TW (Fig. 3).

\section{Haematocrit}

The haematocrit increased significantly in treatments TW and TWNS when the horses arrived to the treatment room. The haematocrit tended to decrease when the twitch was applied. It was significantly decreased after 4, 30 and 60 min in treatment TWNS, TW and TWN, respectively. When the twitch was removed, in treatment TW and TWNS, the haematocrit tended to increase. However, there were no significant differences between treatments (Fig. 4).

\section{Total plasma protein concentration}

The concentration of total plasma protein increased with $4 \%$ in all treatments $(P<0.05)$ when the horses arrived to the treatment room. The concentration remained unchanged in TW, HN and TWN. In treatment TWNS, where the plasma protein concentration was $64 \pm 2 \mathrm{~g} / \mathrm{l}$ in the second sample, the concentration had decreased to $62 \pm 2 \mathrm{~g} / \mathrm{l}(\mathrm{P}<0.05)$ after $30 \mathrm{~min}$, to $58 \pm 2(\mathrm{P}<0.001)$, $57 \pm 2(P<0.001)$ and $57 \pm 1(P<0.001) \mathrm{g} / \mathrm{l}$ after 60,90 and $120 \mathrm{~min}$, respectively. Treatment TWNS led to significantly lower plasma protein concentrations during the last three box samples compared to TWN $(\mathrm{P}<0.05)$.

\section{Discussion}

There were great individual variations in temperament of the five horses, three calm and quiet individuals, one apathetic but tense, and one alert and nervous. The amount of stress an animal perceives is dependent on the duration and intensity of the stressor but also upon the psychologic and physiologic state of the animal (Benson, 1995). One horse tended to be more sedated and quiet during twitching compared to the others while another horse became more upset than before application. Horses that greatly resent the twitch and fight it, may have been abused in the past, and should be restrained in some other way (Vaughan and Allen, 1982). In our study, four of five horses accepted ear holding and tubing but one horse became so excited that we could not insert the tube. Our study therefore confirms that the method of restraint has to be adapted to each individual horse.

Entering the treatment room changed the behaviour of the horses. They became alerted and appeared suspicious, probably due to earlier experiences in the stock. Animals can cope or alleviate stress by engaging in adjunctive activities when they are frustrated and lack control over their environment (Benson, 1995).
One of the calm horses regularly pawed with its front feet when restrained in the stock, but was easy to handle. The behavioural changes when they came to the stock were reflected in the increased haematocrit and plasma protein concentration. These physiological changes indicate an activation of the sympathetic nervous system and fluid transfer from blood plasma to the interstitial space. The concentration of $\beta$-endorphin tended to increase when the horses arrived to the stock but the increase was not significant. The concentration of cortisol was lower when the horses were restrained in the stock compared to the resting value. However, it is important to consider the long time interval between stimulus and increased plasma cortisol concentration. The insertion of the catheter could have led to the higher cortisol values in the first sample and the earlier box rest could be the reason to the lower stock value.

All four treatments induced a stress response in the horses, as judged from the increased cortisol concentrations. Surprisingly, treatment $\mathrm{HN}$ did not induce the highest values of measured stress variables, which was expected from the behaviour of the animals. Only the two treatments TWN and TWNS led to increased $\beta$-endorphin concentrations and these treatments also tended to cause a greater and more long lasting elevation of plasma cortisol. In contrast to earlier studies (McCarthy et al., 1993; McCarthy et al., 1991) our horses did not respond to only twitching with increased plasma $\beta$-endorphin concentrations. The reason for this is difficult to explain. There are great variations in twitching technique and the twitching time can vary. We tried to treat the horses in the same manner and the same person applied the twitch every time. Interestingly, the individual horses responded differently to the twitch, still the $\beta$-endorphin pattern was correlated to the treatment and not to the behaviour of the individual horse.

Earlier studies have shown that twitching decreases the heart rate in the horse (Lagerweij and Nelis, 1984; Matsui et al., 1986). This was confirmed in our study where the heart rate decreased in all treatments except in $\mathrm{HN}$, which did not include twitching. When the twitch was removed the heart rate tended to increase.

Which treatment was the most stressful for the horses? Behaviourally, four of five horses disliked treatment HN most. However, only treatment TWN and TWNS increased the $\beta$-endorphin concentrations and these treatments also tended to cause higher, more long lasting cortisol values. However, even if treatment TWNS was stressful for the horses, the low plasma protein concentration at the end of the experiment indicated that the horses were able to absorb the saline solution and thus the fluid administration was successful. On the other hand, is it possible to inhibit the fluid uptake by stress caused by traditional treatments? Interestingly, plasma arginine vasopressin (AVP), also measured during the study, followed the same pattern as $\beta$-endorphin. The treatments TWN and TWNS showed significantly higher AVP concentrations during the stock period compared to HN (Nyman et al., 1996) and TW (Nyman, unpublished). In conclusion, twitching calmed the horses more efficiently than ear holding, but the latter method of restraint induced the smallest changes in the physiological stress variables. However, to hold the ears correctly is difficult and cannot be generally recommended.

\section{References}

Benson, G. J. (1995): Clinical and hormonal assessment of perioperative distress. Proc. Spring Conf. Ass. Vet. Anest. NaantaliTurku. J. Vet. Anest. In press. 
Hamra, J. G., Kamerling, S. G., Wolfsheimer, K. J. and Bagwell, C. A. (1993): Diurnal variation in plasma ir-beta-endorphin levels and experimental pain threshold in the horse. Life Sciences, 53, $121-129$

Klein, M. J., Deegen, E., Moogen, H. and Hoppen, H. O. (1989): Funktionstest der equinen Nebennierenrinde. Pferdeheilkunde, 5, 225-230.

Lagerweij, E. and Nelis, P. (1984): The twitch in horses: a variant of acupuncture. Science, 225, 1172-1174.

Lagerweij, E., Nelis, C. and van Ree, J. (1982): The twitch. Proceedings of the Association of Veterinarian Anaesthetists of Great Britain and Ireland. Suppl., 10, 44-50.

Matsui, K., Sugano, S. and Amada, A. (1986): Heart rate and ECG response to twitching in thoroughbred foals and mares. Jpn. J. Vet. Sci., 48, 305-312.

McCarthy, R., Jeffcott, L. and Clarke, I. (1993): Preliminary studies on the use of plasma $\beta$-endorphin in horses as an indicator of stress and pain. J. Eq. Vet. Sci., 13, 216-219.

McCarthy, R., Jeffcott, L., Clarke, I., Funder, J., Smith, I. and Wallace, C. A. (1991): Evaluation of stress in horses. Austral. Eq. Vet., 9, 34.

Nyman, S., Hydbring, E. and Dahlborn, K. (1996): Is vasopressin a "stress hormone" in the horse? Pferdeheilkunde, in press.
SAS. (1987): User's Guide: Statistics, version 6.04. SAS Institute Inc., Cary, NC, USA.

Vaughan, J. T. and Allen, R. Jr. (1982): Physical and chemical restraint, In: Equine Medicine and Surgery, 3rd ed, pp 219-228, Ed: Mansmann, R. A., E. S. McAllister and P. W. Pratt. American veterinary publications. Drawer KK, Santa Barbara, California.

Eva Hydbring

Kristina Dahlborn

Department of Animal Physiology

Sara Nyman

Department of Medicine and Surgery

Swedish University of Agricultural Sciences

S-750 07 Uppsala

Sweden

$\mathrm{Fax}+4618672852$

\title{
Colorado State University
}

1996 Continuing Education Programmes

\section{Diagnosis and Treatment of Lameness in the Horse}

\author{
September 4-6, 1996
}

\section{Equine Dentistry}

September 19-20, 1996

Contact: School for Veterinary Medicine, University of Colorado, Fort Collins, CO 80523, Tel.: 001-800-4 579715 